\title{
Project Management Knowledge and Skills for the Construction Industry
}

\author{
Achara Khamaksorn $^{1}$
}

\begin{abstract}
Although it is known that knowledge and competency in project management are important for the construction industry. This report seeks to answer to question: How to develop and implement project management knowledge and skills in the construction industry. The method used to answer the research question is analysis of the ways for developing and implementing the construction project. Findings reveal that scheduling and planning management is a significant knowledge while delegation, leadership, decision making and problem solving are the essential skills for the construction process. Moreover, project manager is a key person who's responsible for the construction project success. It is important that construction project manager must have knowledge and skills in term of management and technical skill. Therefore, project manager should improve their personal knowledge management skills in order to help them develop and implement project management knowledge and skills for their construction project.
\end{abstract}

Keywords-Project Management, Knowledge, Skills, Construction Industry.

\section{INTRODUCTION}

In the changing working environment, the importance of project management is increasing more and more [1, 2]. Project management technique is current issue and a key appliance for developing and implementing strategy in the construction industry [3]. Project management practice is an important issue and well recognized application of techniques, software, knowledge and skills in order to initiate, plan, execute, monitor and control the construction project effectively and efficiently. As Lock (2004) has pointed out, project management define and develop various rules and regulations of technical terms and management skills for the construction project. In construction projects, when project teams manage change situations, knowledge plays a key role. Knowledge on construction project management is a key issue in today's construction industry. Snowden (2002) argues that knowledge can be seen paradoxically, as both a 'thing' and a 'flow' requiring diverse management approaches. Moreover, project success is the satisfaction of stakeholder needs and is measured by the success criteria as identified and agreed at the start of the project. In fact, there are some researches that prove performance of the successful projects is affected by project managers' competencies [6]. Identifying and developing project managers' competencies are becoming more and more important in today's competitive market [7]. Therefore, the purpose of this research is to investigate how to

Chiang Mai University, Thailand. develop and implement project management competency for the construction industry.

\section{LITERATURE REVIEW}

\subsection{Project Management}

Project management is the discipline of initiating, planning, executing, monitoring and controlling, and closing the work of a team to achieve specific goals and meet specific success criteria. A project is a temporary endeavour designed to produce a unique product, service or result with a defined beginning and end undertaken to meet unique goals and objectives, typically to bring about beneficial change or added value [8]. The Project Management Triangle is a model of the constraints of project management. It is a graphic aid where the three attributes show on the corners of the triangle to show opposition. It is useful to help with intentionally choosing project biases, or analysing the goals of a project. It is used to illustrate that project management success is measured by the project team's ability to manage the project, so that the expected results are produced while managing time and cost. Projects need to be performed and delivered under certain constraints. Traditionally, these constraints have been listed as "Quality", "Time", and "Cost". These are also referred to as the "Project Management Triangle," where each side represents a constraint. One side of the triangle cannot be changed without affecting the others. Project management can apply to any project, but it is often tailored to accommodate the specific needs of different and highly specialized industries. For example, the construction industry, which focuses on the delivery of things like buildings, roads, and bridges, has developed its own specialized form of project management that it refers to as Construction project management and for which project managers can become trained and certified in. For each type of project management, project managers develop and utilize repeatable templates that are specific to the industry they're dealing with. This allows project plans to become very thorough and highly repeatable, with the specific intent to increase quality, lower delivery costs, and lower time to deliver project results.

\subsection{Competency of Project Manager}

Project managers in construction are responsible for the overall success of delivering the owner's physical development within the constraints of cost, schedule, quality and safety requirements. A Competent Project Manager is vital to project success, and several studies have highlighted critical skill. Successful projects and organization now focus on ensuring that project managers acquire the core competencies required to be successful in their projects. To manage the project 
professionally and successfully, a project manager needs to possess the required knowledge and skills [9]. The competence (as shown in Figure 1.) presents the integration of all the competence elements required of an effective project manager. The wheel of competence elements is grouped into the relevant competence domains, of which there are three: Technical, Behavioral, and Contextual.

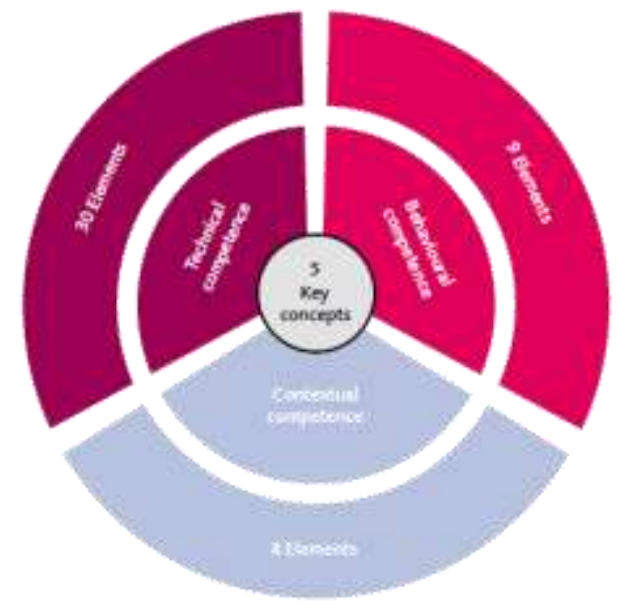

Fig.1 The wheel of competence

\subsection{Knowledge areas and skills of project manager}

A competent project manager is vital to project success, and various studies have highlighted critical expertise [9]. As Hwang and $\mathrm{Ng}$ (2013) has also confirmed the construction industry's growing awareness of the relationship between achieving project success and construction project management competencies. Successful construction firms now focus on assuring that project managers acquire the core competencies required to be successful in their assignments.

\section{MethodOLOGY}

In order to address the information and research question 'How to develop and implement project management knowledge and skills for the construction industry?' The investigation was based on the secondary qualitative approach. A research was collected and carried out from three textbooks and eight journal articles to support the research proposed. The data and information were analysed and synthesized from the literature reviews which focusing on the common sense of project management and Project Manager's Competency and the limited knowledge and skills regarding the construction industry. The research reports were divided into two stages. Firstly, selects the most useful sources for the research. Secondly, eliminates the sources which were only correlated to project management knowledge and skills and Project Manager's Competency for the construction business.

\section{FINDINGS}

This section presents the results of an analysis of knowledge and skill areas which necessary in order to effectively deal with the construction project. The results reveal that expanding and executing project management competency affects the construction project. There have been several cases of project and construction industry indicates that project management process and expertise is essential to the success of the construction industry. According to Bon-Gang and Wei (2013, p.273), "Project Management Institute (PMI) first documented its nine knowledge areas (Integration, Scope, Time, Cost, Quality, Procurement, Risk, Human Resource and Communication) in the Guide to the Project Management Body of Knowledge (PMBOK Guide) in 1987 in an attempt to document and standardizes generally accepted project management information and practices". The Project Management Body of Knowledge is the summary of knowledge within the profession of project management process and all the work required to complete the project successfully [8].

\subsection{Project management knowledge and skills}

According to the research, Hwang and Ng (2013) states that there are eighteen project management competencies must be grasped beyond the project administration expertise. Research results show that scheduling and planning management is the most significant knowledge for the construction project while cost, quality, human resource and communication management are the second most competencies in the construction project (As shown in Table 1).

Moreover, delegation is a key skillfulness which affects the project and construction management while basic technical skill, leadership, decision making and problem-solving are the minority capabilities (As shown in Table 2). Additionally, Edum Fotwe and McCaffer (2000) indicate that there are several of elements define skills and knowledge that are usually offered for developing and implementing the project management competencies in building and construction. Majority functions which explicate and accomplish project management competency in construction are managerial skills and technical skills. A majority of competency for enlarging and achieving project management is the management skill in leadership (98.2\%) while minority expertise is technique skill in planning and scheduling (97.3\%). Lists of knowledge and skills elements for expanding and executing in the construction project are shown in Table 3.

\subsection{Project managers' competencies}

Based on the research gathered from this research, it is clear that the essential knowledge and skills required for an effective project management in the construction industry are responsibilities of project manager. To manage the construction project professional and successfully, a project manager requires knowledge and expertise [9]. A competence project manager is essential to project requirement and success. Construction's project managers are liable for all success of project's delivering within the limitations of scope, time, cost, and quality requirements [10]. Moreover, Project managers' competency has affected the performance of the construction process [7]. 
TABLE I SUMMARY OF KNOWLEDGE AREAS (HWANG AND NG, 2013)

\begin{tabular}{|c|c|c|c|c|}
\hline Essential knowledge area & Dogbegah et al. (2011) & PMI (2008) & Ling (2003) & Odusami (2002) \\
\hline Schedule management and planning & $\mathrm{x}$ & $\mathrm{x}$ & $\mathrm{x}$ & $\mathrm{x}$ \\
\hline Cost Management & $\mathrm{x}$ & $\mathrm{x}$ & $\mathrm{x}$ & \\
\hline Quality Management & $\mathrm{x}$ & $\mathrm{x}$ & $\mathrm{x}$ & \\
\hline HR Management & $\mathrm{x}$ & $\mathrm{x}$ & & $\mathrm{x}$ \\
\hline Risk Management & $\mathrm{x}$ & $\mathrm{x}$ & & \\
\hline Supply chain Management & $\mathrm{x}$ & $\mathrm{x}$ & & \\
\hline Claim Management & $\mathrm{x}$ & & & \\
\hline Knowledge Management & $\mathrm{x}$ & & $\mathrm{x}$ & \\
\hline Health and safe Management & $\mathrm{x}$ & & $\mathrm{x}$ & \\
\hline Conflict and dispute Management & $\mathrm{x}$ & & & \\
\hline Ethical Management & $\mathrm{x}$ & & & \\
\hline Stakeholder Management & $\mathrm{x}$ & & $\mathrm{x}$ & \\
\hline Information Technology Management & $\mathrm{x}$ & & $\mathrm{x}$ & \\
\hline Communication Management & $\mathrm{x}$ & $\mathrm{x}$ & & $\mathrm{x}$ \\
\hline Materials Resources Management & $\mathrm{x}$ & & & \\
\hline Financial Management & $\mathrm{x}$ & & & $\mathrm{x}$ \\
\hline Plant and equipment resources management & $\mathrm{x}$ & & & \\
\hline \multicolumn{5}{|c|}{ TABLE II SUMMARY OF SKILLS (HWANG AND NG, 2013) } \\
\hline Essential skills & E-dum-Fotwe and McCaffler (2000) & Odusami (2002) & Fraser (1999) & $\begin{array}{c}\text { Tett et al. } \\
(2000)\end{array}$ \\
\hline Basic technical skill & $\mathrm{x}$ & $\mathrm{x}$ & $\mathrm{x}$ & \\
\hline Site layout and mobilization & $\mathrm{x}$ & & $\mathrm{x}$ & \\
\hline Estimating and tendering & $\mathrm{x}$ & & $\mathrm{x}$ & \\
\hline Design activities and background & $\mathrm{x}$ & & $\mathrm{x}$ & \\
\hline Reading and understanding drawing & $\mathrm{x}$ & & $\mathrm{x}$ & \\
\hline Technical writing, Drafting contract & $\mathrm{x}$ & & $\mathrm{x}$ & \\
\hline Leadership & $\mathrm{x}$ & $\mathrm{x}$ & $\mathrm{x}$ & \\
\hline Decision Making & $\mathrm{x}$ & $\mathrm{x}$ & & $\mathrm{x}$ \\
\hline Problem solving & $\mathrm{x}$ & $\mathrm{x}$ & & $\mathrm{x}$ \\
\hline Negotiation & $\mathrm{x}$ & $\mathrm{x}$ & & \\
\hline Human behavior & $\mathrm{x}$ & & & \\
\hline Delegation & $\mathrm{x}$ & & $\mathrm{x}$ & $\mathrm{x}$ \\
\hline Team working & $\mathrm{x}$ & & $\mathrm{x}$ & \\
\hline Stress handling & $\mathrm{x}$ & $\mathrm{x}$ & & \\
\hline IT skill & $\mathrm{x}$ & & & \\
\hline Presentation and Report writing & $\mathrm{x}$ & & & $\mathrm{x}$ \\
\hline Public speaking & $\mathrm{x}$ & & & $\mathrm{x}$ \\
\hline Marketing and sales & $\mathrm{x}$ & & & \\
\hline Chairing meeting and Public relation & $\mathrm{x}$ & & $\mathrm{x}$ & \\
\hline
\end{tabular}

\subsection{Knowledge Management practices of construction project manager}

Research results reveal that Knowledge Management (KM) practices are a significant tool that relies on the knowledge and skills initiative by construction's project manager. Therefore, construction project and organization should invest on Personal Knowledge Management (PKM) as the core of personal productivity processes in order to develop and implement project management knowledge and skills for constructions' project manager during their roles [11]. 
TABLE III KNOWLEDGE AND SKILLS ELEMENTS FOR DEVELOPING AND IMPLEMENTING THE PROJECT MANAGEMENT (EDUM-FOTWE AND MCCAFFER, 2000)

\begin{tabular}{|c|c|c|}
\hline Generic PM function & Knowledge and skills & Knowledge and skill factors (Rank) \\
\hline \multirow[t]{4}{*}{ Technical skill } & Planning and scheduling & $97.3(2)$ \\
\hline & Construction Management activities & 89.1 \\
\hline & Basic technical knowledge & 94.5 \\
\hline & Productivity and Cost control & 82.7 \\
\hline \multirow[t]{8}{*}{ Managerial skill } & Leadership & $98.2(1)$ \\
\hline & Delegation & $96.4(3)$ \\
\hline & Negotiation & $95.5(5)$ \\
\hline & Decision Making & 91.8 \\
\hline & Motivation & 90.0 \\
\hline & Team working & 90.0 \\
\hline & Time management & 82.7 \\
\hline & Top management relation & 81.8 \\
\hline \multirow[t]{2}{*}{ Financial skill } & Establishing budgets & 94.3 \\
\hline & Reporting system & 90.6 \\
\hline Legal skill & Drafting contract & 92.4 \\
\hline \multirow[t]{3}{*}{ Communication skill } & Presentation & 95.3 \\
\hline & General and business & 90.6 \\
\hline & Report writing & 88.7 \\
\hline \multirow[t]{2}{*}{ General skills } & Chairing meeting & $96.1(4)$ \\
\hline & Understanding of organization & 84.5 \\
\hline
\end{tabular}

members as well as project performance enhance. Personal

\section{V.DISCUSSION AND CONCLUSION}

This section presents the results of how to enlarge and execute the project management knowledge and skills and how important Project Manager Competency and the implementation of these competencies for a successful project in the construction industry.

\subsection{Project management knowledge and skills}

As it can be seen from findings, planning and scheduling management is a significant competency while delegation, leadership, decision making and problem-solving are the essential proficiency for the construction success. This could be due to the fact that technical skill should focus on planning and scheduling management while managerial skill should addresses leadership, delegation, decision making and problem-solving.

\subsection{Project managers' competencies}

In order to develop and implement project management knowledge and skills for the successful of construction, a project manager needs to practice and develop their project management competencies which required for the construction project. This is probably due to the fact that constructions' project managers usually undertake disciplines and improve their technical skill and management skill by focusing on learning activities and practicing their experiences in order to enlarge and fulfill their professional skill for the development and implementation during the construction project. There is a link between project success and project managers' competencies in the construction industry. In fact, for project success, it is crucial to develop project team. By developing project team, skills and technical competencies of team characteristics of project managers meet the job requirements there is more chance for their success. The importance of project manager's competency come from this point that if the people who are working on the project, to be competent, they would perform effectively which results to the project success and organization success. According to the importance of project manager's competency, it is clear that project manager who are working on the project and would perform effectively which results to the project success and organization success. Moreover, a project manager is a special type of professional with very special skills and training. In order to manage projects and project teams successfully, the project manager should;

- Manage themselves, be good role model, select the right people with appropriate skills and experience, and know how to manage the people issues.

- Practice and improve their knowledge and skill in term of Technical, Behavioral and Contextual Competence especially in Behavioral Competence.

- Share knowledge and experience for teamwork.

- Improve their personal Knowledge Management skills and would like to explore software that might help them in the management of their knowledge.

\subsection{Knowledge Management practices of construction} project manager

Construction's project managers have various practices in the PKM, while they are regularly under the pressure to deliver the project on schedule and budget. The adaptation of the PKM tools by the construction's project managers would lead recovery results in the construction project and decreases the risk of project failure. Moreover, project managers are more willing to improve their personal knowledge management skills that might help them develop and implement their project management knowledge and skills for the construction 
project. This research addressed the question of how to develop and implement project management knowledge and skills in the construction industry and key findings show that there are many knowledge and skill areas essential for developing and implementing. The essential knowledge and skills require for an effective project management of project manager who is a key stakeholder and responsible for the project success. It may well be that project manager acquires various knowledge and experience in technical and managerial areas. Therefore, a project manager should improve their personal knowledge management skills in order to help them develop and implement project management knowledge and skills for the construction project. To conclude, Firstly, Project manager needs to possess the required Knowledge and Skills. Secondly, Project Manager should give priority to Behavioural Competence (Delegation, Leadership, and Team-working). Thirdly, Project Manager should develop their project team. By developing project team, skills and technical competencies of team members as well as project performance enhance. Finally, to ensure their continued relevance in the construction industry, Project Manager often relies on various learning activities that help them to fulfil for the project.

\section{REFERENCES}

[1] Cleland, D. I. (1994). Project Management-Strategic Design and Implementation (Second Edition ed.): McGraw-Hill, Inc.

[2] Turner, J. R. (1993). The Handbook of Project-Based Management (Second Edition ed.). Maidenhead, England: McGraw-Hill.

[3] Tonnquist, B. (2006). Projektledning. Second edition. Stockholm, Sweden: Bonnier Utbildning AB.

[4] Dennis Lock (2004). Project Management in Construction. England: Gower Publishing Limited.

https://doi.org/10.1016/S0263-7863(02)00076-5

[5] Snowden, D. (2002) Complex acts of knowing: paradox and descriptive self-awareness. Journal of Knowledge Management, 6(2), $100-11$. https://doi.org/10.1108/13673270210424639

[6] Jaselskis, E. J., \& Ashley, D. B. (1991). Optimal allocation of project management resources for achieving success. Journal of Construction Engineering and Management, 117 (2), pp.225-230. https://doi.org/10.1061/(asce)0733-9364(1991)117:2(321)

[7] Omidvar, G., Samad, Z. and Alias, A. (2012). Project Management Competency Elements Valued by Project Managers in Construction Industry. IRACST-International Journal of Research in Management \& Technology (IJRMI). ISSN: 2249-9563 Vol.2 No.6 November 2012 Available

http://www.iracst.org/ijrmt/papers/vol2no62012/10vol2no6.pdf

(Accessed: 26 July 2014).

[8] Project Management Institute, Inc. (2004). A guide to project management body of knowledge. PMBOK® guide. - 3rd ed. Project Management Institute, Inc.

[9] Hwang, B. and Ng, W. (2013). Project management knowledge and skills for green construction: Overcoming challenges. International Journal of Project Management 31 (2013). pp.272-284. Available at: http://www.nus.edu.sg/ dpr/files/research_ highlights/2013_10Oct_ProjectManagementKnowledge_Skills_greenC onstruction.pdf (Accessed: 26 July 2014).

[10] Edum-Fotwe, F T. and McCaffer, R. (2000). Developing project management competency: perspectives from the construction industry. International Journal of Project Management 18 (2000). pp.111-124 Available

http://www.researchgate.net/publication/222532855_Developing_proje ct_management_competency_perspectives_from_the_construction_ind ustry/links/0deec51f8f76828d06000000 (Accessed: 26 July 2014).

[11] Ly, E, Anumba, C J and Carrillo, P M (2005). Knowledge management practices of construction project managers. In: Khosrowshahi, $\mathrm{F}$ (Ed.), 21st Annual ARCOM Conference, 7-9 September 2005, SOAS, University of London. Association of Researchers in Construction Management, Vol. 1, 517-26. Available at: http://www.arcom.ac.uk/docs/proceedings/ar2005-0517-0526_Ly_Anumba_and_ Carrillo.pdf (Accessed: 26 July 2014). 